\title{
Çalışma İradesinde Kariyer Kararı Öz-Yetkinliğinin ve Kariyer Karar Verme Belirsizliğine Toleransın Rolü ${ }^{1}$
}

\author{
Furkan KIRAZCI ${ }^{2}$ - Ayşenur BÜYÜKGÖZE KAVAS ${ }^{3}$
}

\author{
Başvuru Tarihi: 20.02.2021 Kabul Tarihi: 01.12.2021 Makale Türü: Araştırma Makalesi
}

\section{Öz}

Bu araştırmanın iki temel amacı bulunmaktadır. Illk olarak üniversite öğrencilerinin sosyoekonomik durumları kontrol altına alındığında çalışma iradesinin kariyer karar verme öz-yetkinliği ve kariyer karar verme belirsizliğine tolerans tarafından ne düzeyde yordandiğını incelemek; ikinci olarak öğrencilerin çalışma iradelerinin cinsiyete göre değişip değiş̧mediğini belirlemektedir. Bu kapsamda, 327 (226 kadın, 100 erkek ve 1 cinsiyet belirtmemiş) üniversite öğrencisinden veri toplanmıştır. Toplanan veriler üzerinde yapılan analizler sonucunda kadınların çalışma iradelerinin erkeklere göre anlaml bir şekilde yüksek olduğu görülmüştür. Ayrıca sosyoekonomik durum kontrol altına alındiğında kariyer karar verme öz-yetkinliği ve kariyer karar verme belirsizliğine tolerans değişkenlerinin birlikte çalışma iradesini anlamlı bir şekilde yordadığı sonucuna ulaşılmıştır. Araştırma bulguları araştırmanın sınırlılıkları çerçevesinde literatüre dayalı olarak tartışılmış ve gelecek araştırmalar için önerilerde bulunulmuştur.

Anahtar Kelimeler: Çalışma İradesi, Kariyer Kararı, Üniversite Öğrencileri

Atıf: Kirazcı, F. ve Büyükgöze Kavas, A. (2021). Çalışma iradesinde kariyer kararı öz-yetkinliğinin ve kariyer karar verme belirsizliğine toleransın rolü. Anadolu Üniversitesi Sosyal Bilimler Dergisi, 21(4), 1071-1088.

\footnotetext{
1 Bu çalışmanın etik kurul izin belgesi Ondokuz Mayıs Üniversitesi Rektörlüğü Sosyal ve Beşeri Bilimler Etik Kurulu'nun 29.11.2019 tarih 11 sayılı toplantısında 2019/423 karar sayısı ile alınmıştır.

2 Ondokuz Mayıs Üniversitesi Eğitim Fakültesi Eğitim Bilimleri Bölümü, furkan.kirazci@omu.edu.tr, ORCID: 0000-0002-8829-3615

3 Ondokuz Mayıs Üniversitesi Eğitim Fakültesi Eğitim Bilimleri Bölümü, aysenur@omu.edu.tr, ORCID: 0000-0001-9072-7040
} 


\title{
The Role of Career Decision Self-Efficacy and Career Decision Ambiguity in Work Volition
}

\author{
Furkan KIRAZCI ${ }^{4}$ - Ayşenur BÜYÜKGÖZE KAVAS ${ }^{5}$
}

Submitted by: 20.02 .2021

Accepted by: 01.12.2021

Article Type: Research Article

\begin{abstract}
The aim of the present study is twofold. The first is to what extent the work volition is predicted by career decision self-efficacy and career decision ambiguity tolerance when socioeconomic status is under control. The second is to examine whether the work volition of undergraduate students changes by gender. Data were collected from 327 (226 women, 100 men, and one missing) undergraduate students. As a result of the analysis, we found that women's work volition was significantly higher than men's. In addition, when the socioeconomic situation is under control, it has been concluded that career decision self-efficacy and career decision ambiguity tolerance together significantly predict the work volition. The research findings were discussed based on the literature within the framework of the limitations of the research, and suggestions were made for future studies.
\end{abstract}

Keywords: Work Volition, Career Decision, Univesity Students

\footnotetext{
${ }^{4}$ Ondokuz Mayıs University Department of Educational Sciences Division of Guidance and Psychological Counseling, furkan.kirazci@omu.edu.tr, ORCID: 0000-0002-8829-3615

${ }^{5}$ Ondokuz Mayıs University Department of Educational Sciences Division of Guidance and Psychological Counseling, aysenur@omu.edu.tr, ORCID: 0000-0001-9072-7040
} 


\section{Giriş}

Kariyer kararı verme süreci geleneksel kariyer gelişim kuramları tarafından kişinin içinde bulunduğu koşullardan bağımsız ve tek başına karar verilip harekete geçilen bir süreç olarak ele alınmaktadır (Brown ve Lent, 2005; Fouad, 2007). Ancak son zamanlarda ortaya çıan kuramsal yaklaşımlarda kişilerin kariyer kararı vermelerini zorlaştıran bağlamsal açıdan çeşitli engeller ve sınıllılıkların olduğu da vurgulanmaktadır (Blustein, 2006; 2008; Duffy, Blustein, Diemer ve Autin, 2016). Bu bağlamda, bireylerin sosyal statü, etnik köken, göç, cinsiyet veya yoksulluk gibi nedenlerden kaynaklanan sınırlılıkları kariyer karar verme süreçlerini ciddi anlamda olumsuz olarak etkileyebilmektedir (Blustein, 2006).

Çalışma Psikolojisi Kuramında (Psychology of Working Theory) araştırmacılar (Duffy, Blustein, Diemer ve Autin, 2016) kişilerin saygın/ insana yakışır bir işe (decent work) ulaşmalarında engel oluşturabilecek sınırlılıkların etkilerinin çeşitli psikolojik yapılarla kırılabileceğini belirtmişler ve bunun için çalışma iradesi (work volition) kavramını kullanmışlardır (Duffy vd., 2016). İlk olarak Blustein $(2006,2008)$ tarafından ele alınan çalışma iradesi kavramı Duffy, Diemer, Perry, Laurenzi ve Torrey (2012, s. 401) tarafından "engellere rağmen mesleki tercihler yapmaya yönelik algılanan kapasite" olarak tanımlanmış ve bu kavramın hem üniversite öğrencilerine (Duffy, Diemer ve Jadidian, 2012) hem de çalışan yetişkinlere (Duffy, Diemer, Perry, Laurenzi ve Torrey, 2012) yönelik ölçekleri geliştirilmiştir.

Literatürde yüksek çalışma iradesine sahip kişilerin kariyer kararı verirken mevcut sinırlılıkları daha anlaşılabilir algıladıkları ve böylece ihtiyaçlarına, ilgi alanlarına ve değerlerine uygun kariyer seçme olanağına daha fazla sahip oldukları belirtilmektedir (Kim, Kim ve Lee, 2018). Ayrıca araştırmalar yüksek çalışma iradesi algısının iş doyumu (Duffy, Bott, Torrey ve Webster, 2013) ve yaşam doyumu (Duffy, Bott, Allan ve Torrey, 2013) ile pozitif yönde ilişkili olduğunu göstermektedir. Son on yıl içinde özellikle yurtdışında üniversite öğrencilerinde çalışma iradesinin incelendiği araştırmalar bulunmaktadır. Örneğin saygın/ insan onuruna yakışır bir iş kavramının İsviçre örneklemi üzerinde incelendiği bir çalışmada saygın iş ile çalışma iradesi arasında pozitif yönde bir ilişkinin olduğu sonucuna varılmıştır (Masdonati, Schreiber, Marcionetti ve Rossier, 2019). Çalışma iradesi ölçeğinin geçerliğinin Çin örneklemi üzerinde test edildiği bir araştırmada ise benzer şekilde çalışma iradesinin saygın işin anlamlı bir yordayıcısı olduğu görülmüştür (Wang, Jia, Hou, Xu, Zhang ve Guo, 2019). Çalışma psikolojisi kuramı (Duffy, Blustein, Diemer ve Autin, 2016) çerçevesinde oluşturulan modelin bir bölümünün Amerikalı kadınlar üzerinde test edildiği bir çalışmada da yukarıdaki çalışmanın sonuçlarına benzer olarak saygın işin yordayıcılarından birinin de çalışma iradesi olduğu sonucuna varılmıştır (England, Duffy, Gensmer, Kim, Buyukgoze-Kavas ve Larson-Konar, 2020). Çalışma iradesinin saygın/insana yakışır iş ile birlikte kariyer uyumluluğu (Buyukgoze-Kavas, Duffy veDouglass, 2015; Duffy, Douglass ve Autin, 2015), mesleki bağllılı (Kim, Kim ve Lee, 2018), iş doyumu (Büyükgöze-Kavas ve Ünal, 2019; Masdonati, vd., 2019) ve istihdam edilebilme algısı (Cheung, Ngo ve Leung, 2018) ile anlamlı düzeyde ilişkili olduğunu gösteren araştırmalar da bulunmaktadır.

$\mathrm{Bu}$ araştırma sonuçlarından hareketle çalışma iradesinin pozitif kariyer kavramlarıyla ilişkili olduğu ve kişilerin iyi oluşlarında merkezi bir role sahip olan saygın işin önemli bir yordayıcısı konumunda bulunduğu söylenebilir. Dolayısıyla kişilerin kariyer gelişimlerinde bu denli pozitif bir etkiye sahip olan çalışma iradesi kavramının yapısının ve kariyer sürecindeki rolünün daha iyi anlaşılabilmesi için kavramın çeşitli kariyer değişkenleriyle ilişkilerinin incelenmesi önem arz etmektedir. Bunun yanında çalışma iradesi üzerinde yordayıcı rolü olan çeşitli değişkenlerin incelenmesi ve ampirik olarak test edilmesi, kişilerin çalışma iradelerini artırmaya yönelik müdahalelerin geliştirilmesine de olanak sağlayabilir. Bu amaçla mevcut araştırmada ilk olarak kariyer karar verme öz-yetkinliği çalışma iradesinin bir yordayıcısı olarak konumlandırılmıştır. 


\section{Çalışma İradesi ve Kariyer Karar Verme Öz-Yetkinliği}

Taylor ve Betz (1983) tarafından ortaya konan kariyer karar verme öz-yetkinliği kavramı, herhangi bir kariyer kararı verme konusunda kişinin kendine duyduğu güveni ifade etmektedir. Diğer bir ifadeyle kariyer karar verme öz-yetinliğine sahip bir kişi kariyeri ile ilgili kararlar verebilmesi için karşısına çıkan görevlerin üstesinden geleceğine dair bir inanca sahiptir. Sosyal Bilişsel Kariyer Kuramının (Lent, Brown ve Hackett, 1994) anahtar kavramlarından biri olan kariyer karar verme öz-yetkinliği üzerine yapılan araştırmalar söz konusu kavramın pek çok pozitif kariyer değişkeniyle ilişkili olduğunu göstermiştir. Bu pozitif kariyer değişkenleri arasında kariyer iyimserliği (Garcia, Restubag, Bordia, Bordia ve Roxas, 2015), çalışma umudu (Juntunen ve Wettersten, 2006), kariyer olgunluğu (Patton ve Creed, 2007), kariyer araştırması (El-Hassan ve Ghalayini, 2020) gibi değişkenler yer almaktadır. Bu araştırmada kişilerin kariyer gelişimlerini kolaylaştırıcı bir etkiye sahip olan kariyer karar verme öz-yetkinliği kavramının çalışma iradesi üzerinde de anlamlı bir role sahip olduğu düşünülmektedir.

Çalışma iradesi ve kariyer karar verme öz-yetkinliği kavramları incelendiğinde, iki değişkenin anlamsal olarak birbirine benzer olduğu görülmektedir. Fakat araştırmacılar çalışma iradesinin kişinin kariyer karar verme sürecinde hissettiği kontrol duygusuna vurgu yaptığını, kariyer karar verme öz-yetkinliğinin ise bu süreçte kişinin kendisine olan güven duygusunu vurguladığını belirtmişlerdir (Duffy, Douglass ve Autin, 2015). Mevcut çalışmada kariyer karar verme öz-yetkinliğinin çalışma iradesini yordayan değişkenlerden biri olarak seçilmesinin sebebi, kişilerin süreç içinde kendilerine duydukları güvenin, süreç üzerindeki kontrol duygularını etkileyebileceğine olan varsayımdır.

Literatürde kariyer karar verme öz-yetkinliğinin çalışma iradesinin bir yordayıcısı olarak incelendiği herhangi bir çalışmaya rastlanmamıştır. Son yıllarda yapılan araştırmalar çalışma iradesi ile çalışma öz-yetkinliği (work self-efficacy) (Duffy, Bott, Torrey ve Webster, 2013), iş arama becerileri öz-yetkinliği (Duffy, Bott, Allan ve Torrey, 2013) ve kariyer karar verme öz-yetkinliği (Duffy, Douglass ve Autin, 2015; Jadidian ve Duffy, 2012) arasında pozitif yönde ilişki bulmuşlardır. Fakat söz konusu ilişkiler yalnızca korelasyon analizi temelinde ele alınmış, herhangi bir yordayıcılık ilişkisine bakılmamıştır. Yukarıda da söz edildiği üzere çalışma iradesi kavramının yapısının daha ayrıntılı bir şekilde ele alınması amacıyla mevcut araştırmada iki değişken arasında bir yordayıcılık ilişkisi kurulmaya çalışılmıştır. Bu sayede hem çalışma iradesinin kariyer gelişimi sürecindeki öneminin daha iyi anlaşılmasına hem de çalışma iradesi ile ilgili geliştirilecek müdahale programlarının kavramsal zemininin oluşturulmasına yönelik katkı sağlanacağı düşünülmektedir.

\section{Çalışma İradesi ve Kariyer Karar Verme Belirsizliğine Tolerans}

Mevcut araştırmada kariyer karar verme öz-yetkinliğinden ayrı olarak çalışma iradesini yordayan bir diğer değişkenin ise kariyer karar verme belirsizliğine tolerans olduğu varsayılmaktadır. Kariyer karar verme süreci büyük oranda öznel bir süreç olarak görülmekte ve bu süreçte kişinin sahip olduğu sinırlılıklar ya da ötekileşme durumu bu süreci etkileyici bir rol üstlenmektedir (Duffy vd., 2016). Chen ve Fouad (2013), kişilerin etnik kökenlerinin olumsuz etkileri gibi sınırlılıkların, kişilerin kariyer yollarını daha da belirsiz hale getirdiğini ve bunun da kariyer sürecini olumsuz yönde etkilediğini belirtmektedir. Xu (2020) ise belirsizlikten kaçınma eğiliminin kişinin mevcut sınırllıklarının kariyer karar verme sürecine yapacağı olumsuz etkiyi daha da artırabileceğini belirtmiş ve kariyer karar verme belirsizliğine tolerans ile çalışma iradesi arasında bir ilişki olabileceğine dikkat çekmiştir. Kariyer karar verme sürecinde belirsizliğe toleransın etkisini inceleyen Xu ve Tracey (2014a; 2014b), belirsizliğe toleransın kariyer karar verme sürecinin “anahtar bir kavramı” olduğunu belirtmişlerdir. Aynı araştırmacılar belirsizliğe tolerans ile kariyer kararsızlı̆̆ı arasındaki ilişkiyi inceleyen çalışmalarında iki değişken arasında negatif yönlü bir ilişkinin olduğu sonucuna varmışlardır. İlerleyen çalışmalarda araştırmacılar belirsizliğe tolerans kavramını kariyer alanına uyarlayarak kariyer karar verme belirsizliğine tolerans (KKVBT) kavramını ortaya koymuşlardır (Xu ve Tracey, 2015). KKVBT kavramı üç boyut halinde ele alınmıştır. İlk boyut olan “tercih” kişilerin kariyer sürecinde karşılaştıkları belirsizliklerden 
hoşlanmaları ve bunları istemelerini ifade ederken, "tolerans" boyutu bu belirsizliklerden hoşlanmama fakat belirsizlikleri tolere edebilmeye atıfta bulunmaktadır. KKVBT’nin üçüncü boyutu olan “isteksizlik" ise kariyer karar verme sürecindeki belirsizlikleri istememe ve bu belirsizliklerden kaçınmayı ifade etmektedir (Xu ve Tracey, 2015). Araştırmalarda (Storme, Celik ve Myszkowski, 2019; Xu ve Tracey, 2015) KKVBT’nin kariyer karar verme sürecinin önemli kavramlarından kariyer karar verme öz-yetkinliği ve kariyer uyumluluğu ile pozitif yönde ilişkili olduğu rapor edilmektedir. Kariyer karar verme belirsizliğine toleransı konu alan diğer çalışmalarda ise KKVBT’nin psikolojik iyi oluş (Park, Garrison ve Liu, 2018), kariyer araştırması (Xu, Hou, Tracey ve Zhang, 2016), iş doyumu ve yaşam doyumu (Xu, 2020) gibi değişkenlerle pozitif yönde ilişkili olduğu görülmüştür. $\mathrm{Bu}$ araştırmada ise KKVBT değişkeni çalışma iradesinin bir yordayıcısı olarak konumlandırılmıştır. Yukarıda da belirtildiği gibi kişilerin sahip olduğu sınırlılıklar (ekonomik sınırlılıklar, ötekileştirilme vb.) kariyer karar verme süreçlerinde belirsizliği daha da artırmaktadır (Chen ve Fouad, 2013). Dolayısıyla çeşitli sınırlılıklara sahip olan bir kişi, bir kariyer kararı verebilmek için sınırlılıklardan kaynaklanan belirsizlikleri bir şekilde tolere edebilmelidir. Bu durumda kişinin karşılaştığı veya sahip olduğu sınırlılıklara karşın kariyeri konusunda bir karar verebileceğine yönelik algısı olarak görülen çalışma iradesinin olması için kişinin bir dereceye kadar belirsizliği tolere edebilmesi gerekmektedir. Bu düşünceden hareketle mevcut araştırmada kariyer karar verme belirsizliğine toleransın çalışma iradesini anlamlı bir şekilde yordayacağ 1 varsayılmaktadır.

\section{Çalışma İradesi, Sosyoekonomik Durum ve Cinsiyet}

Literatürde çalışma iradesininin sosyoekonomik durum, cinsiyet ve cinsel yönelim gibi farklı demografik değişkenlerden de etkilenebileceği ileri sürülmektedir (Blustein, Kenna, Gill ve Devoy, 2008). Buradan hareketle mevcut araştırmada Türk örnekleminde çalışma iradesinin kadınlar ve erkeklerde değişiklik gösterip göstermediği incelenecektir. Diğer taraftan kişilerin sosyoekonomik durumlarının da çalışma iradesi üzerinde etkili olabileceği düşünülmektedir. Örneğin, Duffy vd., (2016) kişilerin maddi güçlerini ve eğitim seviyelerini ifade eden sosyal sınıf ile çalışma iradesi arasında pozitif yönde anlamlı düzeyde bir ilişki olduğunu belirtmiştir. Benzer olarak Autin, Douglass, Duffy, England ve Allan (2017) tarafından yapılan bir başka çalışmada da kişilerin sosyal statüleri ile çalışma iradelerinin pozitif yönde ilişkili olduğu sonucuna varılmıştır. Kişilerin sosyoekonomik durumları ve sosyal statüleri dışarıdan yapılacak müdahalelerle psikolojik değişkenlere kıyasla nispeten daha az değişiklik göstermektedir. Dolayısıyla mevcut çalışmada, çalışma iradesini yordamak için yapılan hiyerarşik regresyon analizine kişilerin sosyoekonomik durumları kontrol değişkeni olarak dahil edilmiştir. Böylelikle çalışma iradesinin açıklanmasında kariyer karar verme belirsizliğine toleransın ve kariyer karar verme öz-yetkinliğinin açıklama gücünün daha net bir şekilde görülmesi hedeflenmiştir.

Sonuç olarak, bu çalışmanın iki temel amacı bulunmaktadır. Bunlardan ilki; üniversite öğrencilerinin sosyoekonomik durumları kontrol altına alındığında çalışma iradesinin kariyer karar verme öz-yetkinliği ve kariyer karar verme belirsizliğine tolerans tarafından ne düzeyde yordandığını incelemek; ikincisi ise çalışma iradesinin cinsiyete göre anlamlı bir fark gösterip göstermediğini belirlemektir. Bu bağlamda çalışma iradesinin yordayıcı değişkenlerinin belirlenmesinin hem bu kavramın kuramsal yapısının daha iyi bir şekilde anlaşılmasını sağlayacağı hem de kariyer psikolojik danışmanlığı uygulamalarını daha da etkili hale getirebileceği umulmaktadır.

Bu bağlamda çalışmanın amacına yönelik olarak aşağıdaki hipotezler geliştirilmiştir.

Hipotez 1: Sosyoekonomik durum değişkeni kontrol altına alındığında kariyer karar verme belirsizliğine toleransın alt boyutları ve kariyer karar verme öz-yetkinliği birlikte çalışma iradesini anlamlı şekilde yordamaktadır.

Hipotez 2: Çalışma iradesi cinsiyete göre anlamlı bir farklılık göstermektedir. 


\section{Yöntem}

\section{Katılımcilar}

Araştırmanın örneklemi 327 (226 kadın, 100 erkek, 1 cinsiyet belirtmemiş) üniversite öğrencisinden oluşmaktadır. Katılımcıların yaşları 19 ile $38(\bar{x}=21.61$; Ss $=1.89)$ arasında değişmektedir. Çalışma grubunda veri toplarken olasılığa dayalı olmayan örnekleme yöntemlerinden "kolay ulaşılabilir örnekleme" yöntemi kullanılmıştır. Katılımcıların öğrenim gördükleri fakülteler; eğitim $(95, \% 29,1)$, güzel sanatlar (85, \%26), mühendislik (60, \%18.3), diş hekimliği (42, \%12.8), fen-edebiyat (37, \%11.3) olarak sıralanmaktadır.

Araştırmada veri toplama süreci öncesinde ilk araştırmacı tarafından kendi üniversitesinin sosyal ve beşeri bilimler etik kurulundan gerekli izin alınmıştır. Etik izin alındıktan sonra veri toplama formlarına ait çoğaltma işlemi yapılmış ve farklı fakültelerdeki öğretim elemanları ile iletişime geçilerek araştırmanın amacı anlatılmıştır. Dersinde veri toplanmasına izin veren öğretim elemanlarından randevu alınarak ilgili derslere gidilmiş ve araştırma tanıtılarak gönüllü olan öğrencilerden veri toplanmıştır. Katılımcılar tarafından ölçek formlarının doldurulması yaklaşık olarak 10 dakika sürmüştür.

\section{Veri Toplama Araçları}

Çalışma İradesi Ölçeği-Öğrenci Formu (Çİ̈-ÖF): Çalışma İradesi Ölçeği - Öğrenci Formu Duffy, Diemer ve Jadidian (2012) tarafından bireylerin sınıllılıklarına rağmen mesleki karar verebilmeye yönelik algılarını ölçmek için geliştirilmiştir. Ölçek, "irade" (örn. "İstediğim işleri seçebileceğim”) ve "engel” (örn. "Gelecekteki iş seçimimde ne istediğimin çok az etkisi olacaktır.") olmak üzere iki boyutlu bir yapıya sahiptir. Toplam 16 maddeden oluşan Çalışma İradesi Ölçeği 7 'li likert ( $1=$ hiç katılmıyorum, $7=$ tamamen katılıyorum) tipinde bir puanlama sistemine sahiptir. Ölçeğin geliştirilme çalışmasında Duffy vd., (2012) iki ayrı örneklem grubu üzerinde açımlayıcı ve doğrulayıcı faktör analizi yapmış ve analizler sonucunda iki boyutlu yapının iyi uyum gösterdiğini rapor etmişlerdir. Ölçeğin toplam puanı için hesaplanan Cronbach alpha iç tutarlılık katsayısı .92 bulunmuştur (Duffy vd., 2012).

Çalışma İradesi Ölçeği - Öğrenci Formunun Türkçeye uyarlama çalışması Buyukgoze-Kavas, Duffy ve Douglass (2015) tarafından yapılmıştır. Uyarlama çalışması kapsamında yapılan doğrulayıcı faktör analizi sonucunda ölçeğin Türkçe formunun orijinalindekine benzer olarak iki faktörlü ve 16 maddeli yapıya sahip olduğu sonucuna varılmıştır. Ayrıca ölçeğin Cronbach alpha güvenirlik katsayısı toplam puanı için .89, irade alt boyutu için .78 ve sınırlılık alt boyutu için ise .93 olarak rapor edilmiştir. Bu araştırmada elde edilen verilerle hesaplanan iç tutarlık katsayısı ise toplam puan için .82, irade alt boyutu için .80 ve sinırlılık alt boyutu için ise .79 'dur.

Kariyer Karar Verme Öz-Yetkinlik Ölçeği-Kısa Formu (KKVÖYÖ-KF): Betz, Klein ve Taylor (1996) tarafından geliştirilen KKVÖYÖ'nün kısa formu 25 maddeden oluşmaktadır (örn. “İyi bir özgeçmiş hazırlama”, "İş görüşmesi sürecinin başarılı bir şekilde üstesinden gelme”). Ölçek 5’li likert tipinde puanlanmaktadır (1= Hiç güvenmiyorum, 5= Tamamen güveniyorum). Ölçekten alınan yüksek puanlar kişinin kariyeri için karar verebilmesine olan güveninin yüksek olduğuna işaret etmektedir. Ölçeğin tüm maddeleri için iç tutarlılık katsayısı Betz, Klein ve Taylor (1996) tarafından .94 ve test-tekrar test katsayısı ise .83 olarak rapor edilmiştir.

KKVÖY ölçeğinin Türkçeye uyarlama çalışması Büyükgöze-Kavas $(2011,2014)$ tarafından yapılmıştır. Ölçeğin Türkçe formunun iç tutarlılık katsayısı Büyükgöze-Kavas (2011) tarafından .92, test-tekrar test güvenirlik katsayısı ise .91 olarak bulunmuştur. Ayrıca ölçeğin uyum geçerliğini tespit etmek amacıyla Genel Öz-yeterlik Ölçeği ile korelasyonuna bakılmış ve iki ölçek arasındaki ilişkinin .65 düzeyinde olduğu belirtilmiştir (Büyükgöze-Kavas, 2011). Bu araştırma kapsamında ise ölçeğin iç tutarlık katsayısı 92 olarak hesaplanmıştır.

Kariyer Karar Verme Belirsizliğine Tolerans Ölçeği (KKVBTÖ): Xu ve Tracey (2015) tarafından geliştirilen KKVBTÖ bireylerin kariyer karar verme süreçlerinde karşılaştıkları belirsizlik durumlarını tolere edebilme 
seviyelerini ölçmeyi amaçlamaktadır. Toplam 18 maddeden oluşan ölçek üç boyutlu (tercih, tolerans ve isteksizlik) bir yapıya sahiptir. Ölçek 7'li likert puanlama sitemine dayalı olarak puanlanmakta ve toplam puan hesaplanmamaktadır. Bu nedenle her boyut kendi içinde hesaplanmaktadır. Tercih alt boyutu bireylerin kariyer karar verme sürecindeki belirsizlikleri olumlu bir şekilde karşllama eğilimlerini ölçmektedir (örn. "Kişiliğimin ve ilgilerimin birçok yönünü keşfetmeye ilgi duyarım"). Tolerans alt boyutu ise bireylerin belirsizliklere tahammül etme ve başa çıkabilme düzeylerini ölçmeyi amaçlamaktadır (örn. "Birden fazla seçenek eşit derecede çekici göründüğünde bir seçim yapabilirim”). Son olarak isteksizlik alt boyutu ise bireylerin karar verme süreçlerindeki belirsizliklerden kaçınma ve bu belirsizlikleri istememe eğilimlerini göstermektedir (örn. "Karmaşık kariyer karar verme görevlerinden kaçınmaya çalışırım”). Ölçeğin ölçüt geçerliği için öz-yetkinlik, kariyer kararsızlığı ve belirsizliğe tolerans ölçekleri ile ilişkisine bakılmış ve aralarında anlamlı ilişkiler olduğu belirtilmiştir (Xu ve Tracey, 2015). Ayrıca alt boyutların iç tutarlılık katsayıları ise sırasıyla tercih için .83, tolerans için .70 ve isteksizlik için .81 olarak bulunmuştur.

KKVBTÖ'nün Türkçeye uyarlama çalışması Kirazcı ve Öztemel (2021) tarafından gerçekleştirilmiştir. Ölçeğin yapı geçerliğini kontrol etmek amacıyla doğrulayıcı faktör analizi yapılmış ve orijinal yapısına benzer olarak üç faktörlü yapının iyi uyum gösterdiği görülmüştür. Ölçeğin Türkçe formunun iç tutarlılık katsayıları tercih alt boyutu için .67, tolerans alt boyutu için .70 ve isteksizlik alt boyutu için .71 olarak bulunmuştur. Yapılan test-tekrar test sonucuna göre ise iki uygulama arasında tercih alt boyutu için .53, tolerans alt boyutu için .59 ve isteksizlik alt boyutu için .51 düzeyinde ilişki bulunmuştur. Mevcut araştırmada ise ölçeğin iç tutarlılık katsayıları sırasıyla tercih alt boyutu için .67, tolerans alt boyut için .77 ve isteksizlik alt boyutu için .74 olarak hesaplanmıştır.

Kişisel Bilgi Formu: Kişisel bilgi formunda araştırmaya katılan kişilerin sırasıyla yaşları, cinsiyetleri, sosyoekonomik durumları ve öğrenim gördükleri fakülteler sorulmuştur. Ayrıca ölçek formlarının doldurulması ve yapılan çalışma hakkında kısaca bilgi verilmiştir.

\section{Verilerin Analizi}

Verilerin analizinde sosyoekonomik durum, kariyer karar verme belirsizliğine tolerans ve kariyer karar verme öz-yetkinliği'nin çalışma iradesini ne derecede yordadığını belirlemek için hiyerarşik regresyon analizi ve çalışma iradesinin cinsiyete göre farklılık gösterip göstermediğini belirlemek için ise bağımsız örneklemler $t$ testi kullanılmıştır. Analizler SPSS 22 paket programı aracıllğ̆ıla gerçekleştirilmiştir.

\section{Bulgular}

\section{Ön bulgular}

Çalışma kapsamında veri analizinde kullanılacak olan hiyerarşik regresyon analizi, korelasyon analizi ve bağımsız örneklemler $t$-testi yapılmadan önce ilgili varsayımlar test edilmiştir. Bu bağlamda, uç değerlerin olup olmaması, çoklu ortak doğrusallığın bulunmaması ve verilerin normal dağılım göstermesi gibi regresyon analizine özgü varsayımlar kontrol edilmiş ve veri setinin gerekli varsayımları karşıladığı sonucuna ulaşıldıktan sonra analizlere başlanmıştır.

Mevcut araştırmada ilk olarak kullanılan ölçme araçlarının güvenirlik katsayıları incelenmiş ve geliştirilme ve/veya uyarlanma aşamalarındaki gibi yeterli güvenirlik katsayılarına sahip olup olmadıkları değerlendirilmiştir. Veri toplama araçları kısmında söz konusu araçlar tanıtılırken bu araçların mevcut araştırmadaki veriler üzerinden hesaplanan güvenirlik katsayılarına da yer verilmiştir. Buna göre elde edilen katsayıların ilgili alanyazında tavsiye edilen Cronbach alpha değerini karşıladığı söylenebilir.

Analizler öncesinde veri setinin kontrolü için veri setinde uç değer bulunup bulunmadığı incelenmiştir. $\mathrm{Bu}$ amaçla ilk olarak verilerin Mahalanobis uzaklıkları hesaplanmış ve Tabachnick ve Fidell (2015)'in önerisi 
doğrultusunda kritik ki-kare değerine göre karşılaştırma yapılmıştır. Analize giren bağımsız değişkenlerin sayısı göz önüne alındığında kritik değerin 22.458 olduğu sonucuna ulaşılmış ve bu değeri aşan bir katılımcı veri setinden çıkarılmıştır (Mah.=23.286; id=216). Veri setindeki uç değerin çıkarılmasının ardından verilerin normallik sayıltıları incelenmiş ve bu amaçla değişkenlerin çarpıklık ve basıklık katsayıları hesaplanmıştır. Elde edilen sonuca göre her bir değişkenin basıklık ve çarpıklık katsayılarının -1 ile +1 arasında değiştiği görülmüştür. Çarpıklık ve basıklık katsayılarındaki bu sonuç ise her bir değişkenin tek başına normal dağılıma sahip olduğunu göstermektedir (Çokluk, Şekercioğlu ve Büyüköztürk, 2014). Buna ek olarak değişkenlerin ortak normallik varsayımını karşılayıp karşılamadığını belirlemek için ise "Regresyon İçin Standart Hale Getirilmiş Artıkların Normal Olasılık Grafiğì” ile histogram ve saçılma grafikleri incelenmiştir. Grafiklerden elde edilen sonuca göre verilerin ortak normallik varsayımına ek olarak doğrusallık, eş varyanslılık ve hataların bağımsızlı̆̆ı varsayımlarını da karşıladığı sonucuna varılmıştır. Grafiklere ek olarak hataların bağımsızlığı varsayımını kontrol etmek için Durbin-Watson istatistiğinden de yararlanılmıştır. İlgili alanyazında hataların bağımsızlığı varsayımının karşılanması için Durbin-Watson katsayısının 1 ile 3 arasında yer alması gerektiği belirtilmektedir (Field, 2013, s. 390; akt. Sarı, Kabadayı ve Şahin, 2017). Dolayısıyla hesaplamalar sonucunda elde edilen 1.70 değerindeki Durbin-Watson katsayısının hataların bağımsız olduğuna kanıt oluşturduğu söylenebilir.

\section{Çalışma İradesinin Sosyoekonomik Durum, Kariyer Karar Verme Belirsizliğine Tolerans ve Kariyer Karar Verme Öz Yetkinliği Tarafından Yordanması}

Üniversite öğrencilerinin sosyoekonomik durumları, kariyer karar verme öz-yetkinliği puanları ve kariyer karar verme belirsizliğine tolerans puanları, standart sapmalar ve değişkenler arasındaki korelasyon katsayıları Tablo 1'de verilmektedir.

Tablo 1

Sosyoekonomik Durum, KKVÖYÖ ve KKVBT Ölçeği Alt Boyutlarından Alınan Toplam Puanlar, Standart Sapma ve Korelasyon Katsaylları

\begin{tabular}{|c|c|c|c|c|c|c|c|c|c|}
\hline & Tolerans & VIF & $X$ & Ss & 1 & 2 & 3 & 4 & 5 \\
\hline 1. Sos.Ek. & .961 & 1.040 & 5.47 & 1.62 & 1.00 & $.16^{* * *}$ & .07 & $.09^{*}$ & $-.12^{* *}$ \\
\hline 2. KKVÖY & .837 & 1.194 & 94.40 & 15.02 & & 1.00 & $.32^{* * *}$ & $.32^{* * *}$ & $-.13^{* *}$ \\
\hline 3. Tercih & .775 & 1.290 & 27.73 & 4.75 & & & 1.00 & $.42^{* * *}$ & .04 \\
\hline 4. Tolerans & .769 & 1.300 & 26.60 & 6.45 & & & & 1.00 & $-.13^{* *}$ \\
\hline 5. İsteksizlik & .948 & 1.055 & 23.85 & 6.72 & & & & & 1.00 \\
\hline
\end{tabular}

Tablo 1 incelendiğinde sosyoekonomik durum ile kariyer karar verme öz-yetkinliği arasında düşük düzeyde pozitif yönde anlamlı bir ilişki olduğu görülmektedir $(r=.16 ; p<.001)$. Sosyoekonomik durum ile Kariyer Karar Verme Belirsizliğine Tolerans Ölçeğinin alt boyutları olan tercih $(r=.07 ; p>.05)$ arasında anlamlı bir ilişki görülmezken, tolerans $(r=.09 ; p<.05)$ ile pozitif yönde, isteksizlik $(r=-.12 ; p<.01)$ ile negatif yönde anlamlı ilişki olduğu görülmüştür. Bu bulgularla benzer olarak, KKVÖY ölçeği ile KKVBT ölçeğinin alt boyutları olan tercih $(r=.31 ; p<.001)$ ve tolerans $(r=.32 ; p<.001)$ arasında pozitif yönde anlamlı bir ilişki bulunurken, isteksizlik $(r=-.13 ; p<.01)$ ile negatif yönde düşük düzeyli bir ilişki bulunmuştur. Değişkenler 
arasındaki korelasyon katsayıları incelendiğinde en yüksek korelasyon katsayısının .42 olduğu ve değişkenler arasında çoklu ortak doğrusallığın olmadığı görülmektedir. Diğer taraftan modelde bir bağımsız değişkenin diğer bağımsız değişkenlerce ne kadarının açıklanmadığını gösteren tolerans değerlerinin .775 ile .961 arasında değiştiği görülmektedir. Literatürde tolerans değerinin .10'dan büyük olmasının çoklu ortak doğrusallığın olmadığına işaret ettiği belirtilmektedir (Pallant, 2017). Yine benzer şekilde çoklu ortak doğrusallık varsayımının olmadığının diğer bir göstergesi ise varyans şişirme faktörüdür (VIF). VIF değerinin ise 10'dan küçük olması beklenmektedir (Pallant, 2017). Tablo 1'de görüldüğü üzere en yüksek VIF değeri 1.300 olarak hesaplanmıştır. $\mathrm{Bu}$ sonuçlardan hareketle yapılacak hiyerarşik regresyon analizinin çoklu ortak doğrusallık varsayımının karşılandığı söylenebilir.

Regresyon analizinin diğer varsayımlarının karşılanıp karşılanmadığını incelemek için ise regresyon için standart hale getirilmiş artığın normal olasılık grafiği ve saçılım grafiği incelenmiştir. Grafik sonuçlarına göre normallik, eş varyanslılık ve doğrusallık gibi regresyon varsayımlarının sağlandığı söylenebilir. Veri setinde uç değerlerin olup olmadığını incelemek için ise saçılım grafiğine ek olarak verilerin Mahalonobis uzaklıkları hesaplanmıştır. Tabachnick ve Fidell (2013)'in kritik değer tablosuna göre Mahalonobis uzaklıkları kıyaslandığında kritik değerin 20.515 olduğu ve bu değeri aşan yalnızca bir gözlemin olduğu görülmüştür. Veri setinin genişliğine dayanarak kritik değeri aşan gözlemin yine veri setinde kalmasına karar verilerek hiyerarşik regresyon analizi yapılmıştır. Sosyoekonomik durum kontrol altına alındığında kariyer karar verme özyetkinliği ile kariyer karar verme belirsizliğine toleransın birlikte çalışma iradesini ne derece yordadığını incelemek için yapılan hiyerarşik regresyon analizi Tablo 2’te verilmektedir.

Tablo 2

Çalışma İradesi Ölçeğinden Alınan Toplam Puanların Yordanmasına ilişkin Çoklu Doğrusal Regresyon Analizi Sonuçları

\begin{tabular}{|c|c|c|c|c|c|c|c|c|}
\hline Model & Yordayan & B & $\begin{array}{l}\text { Standart } \\
\text { Hata }\end{array}$ & $\beta$ & $\mathrm{t}$ & $\mathrm{F}$ & $\mathrm{R}^{2}$ & $\Delta \mathrm{R}^{2}$ \\
\hline \multirow{2}{*}{1} & Sabit & 66.659 & 2.653 & & $25.127^{* *}$ & \multirow{2}{*}{$32.608^{* *}$} & \multirow{2}{*}{.091} & \multirow{2}{*}{.088} \\
\hline & Sos.Ek. & 2.655 & .465 & .302 & $5.710^{* *}$ & & & \\
\hline \multirow{6}{*}{2} & Sabit & 29.360 & 5.725 & & $5.128^{* *}$ & \multirow{6}{*}{$39.273^{* *}$} & \multirow{6}{*}{.380} & \multirow{6}{*}{.370} \\
\hline & "Sos.Ek. & 1.750 & .394 & .199 & $4.438^{* *}$ & & & \\
\hline & Tercih & .277 & .150 & .092 & $1.847^{*}$ & & & \\
\hline & Tolerans & .030 & .111 & .013 & .267 & & & \\
\hline & İsteksizlik & -.332 & .096 & -.156 & $-3.463^{*}$ & & & \\
\hline & **KKVÖY & .442 & .046 & .465 & $9.674^{* *}$ & & & \\
\hline
\end{tabular}

Hiyerarşik regresyon analizi yapılırken analize ilk olarak sosyoekonomik durum değişkeni dahil edilmiştir. İkinci kısımda ise kariyer karar verme belirsizliğine tolerans değişkeninin alt boyutları ve kariyer karar verme öz-yetkinliği analize sokulmuştur. Tablo 2 incelendiğinde analize giren yordayıcı değişkenlerin bir bütün olarak çalışma iradesini anlamlı bir düzeyde $\% 38$ oranında yordadığ 1 görülmektedir $\left(\mathrm{R}^{2}=.38, \mathrm{~F}(5-326)=\right.$ 39.273, $p<.001)$. Sosyoekonomik durum kontrol altına alındığında tercih, tolerans ve isteksizlik ile kariyer 
karar verme öz-yetkinliği birlikte çalışma iradesini \%29 oranında açıklamaktadır. Değişkenlerin beta katsayıları dikkate alındığında sosyoekonomik durumdaki bir birimlik artışın çalışma iradesinde 1.750'lik bir artışa yol açtı̆̆ $(\beta=1.750 ; p<.001)$, KKVÖY değişkenindeki bir birimlik artışın ise çalışma iradesi üzerinde .442 'lik bir artışa neden olduğu $(\beta=.442 ; p<.001)$ görülmektedir. KKVBT’nin alt boyutları olan tercih alt boyutundaki bir birimlik artışın çalışma iradesi üzerinde .277 'lik bir artışa $(\beta=.277 ; p<.005)$, isteksizlik alt boyutundaki bir birimlik artışın ise çalışma iradesi üzerinde $-.375^{\prime}$ lik bir azalmaya yol açtığı $(\beta=-.332 ; p<$ .005) görülmektedir. Buna karşın tolerans alt boyutunun tek başına çalışma iradesi üzerinde anlamlı bir yordayıcılığa sahip olmadığı sonucuna ulaşılmıştır.

Yapılan hiyerarşik regresyon analizi sonuçlarının etki büyüklügünü incelemek amacıyla regresyon analizleri için önerilen $\mathrm{f}^{2}$ değeri hesaplanmıştır. Etki büyüklüğü, " $\mathrm{h}_{0}$ hipotezleri ile alternatif hipotezler arasındaki farkın büyüklügü̈" olarak tanımlanmaktadır ve bu değer araştırma sonuçlarının pratikteki anlamlılı̆̆ının bir göstergesi niteliğindedir (Özsoy ve Özsoy, 2013). Yapılan hesaplama sonucunda mevcut araştırmanın etki büyüklüğünün Cohen (1988)'in sınıflandırmasına göre geniş bir etkiye sahip olduğu sonucuna ulaşılmıştır $\left(\mathrm{f}^{2}=\right.$ .613). Bu veriden hareketle yapılan analizde elde edilen sonuçların pratikte de anlamlı olduğu söylenebilir.

\section{Çalışma İradesinin Cinsiyete Göre İncelenmesi}

Çalışma İradesi Ölçeği’nden alınan toplam puanların cinsiyete göre anlamlı bir şekilde farklılaşıp farklılaşmadığını test etmek için yapılan bağımsız örneklemler $t$-testi sonucu, cinsiyetler arasındaki puan ortalamaları ve standart sapmaları Tablo 3'de verilmektedir.

Tablo 3

Cinsiyete Göre Çalışma İradesi Ölçeğinden Alınan Puan Ortalamaları, Standart Sapmaları ve $t$ Testi Sonucu

\begin{tabular}{lllllll}
\hline & Cinsiyet & $\mathrm{N}$ & $\mathrm{X}$ & Ss & $t$ & $p$ \\
\hline $\begin{array}{c}\text { Çalışma } \\
\text { İradesi }\end{array}$ & Kadın & 226 & 82,21 & 14,20 & 2.038 & $.042^{*}$ \\
\hline${ }^{p<.05}$ & Erkek & 100 & 78,73 & 14.24 & & \\
\hline
\end{tabular}

Araştırmadan elde edilen verilere göre kadınların Çalışma İradesi Ölçeğinden aldıkları toplam puanların ortalaması 82.21 iken, erkeklerin ortalaması 78.73 olarak bulunmuştur. Cinsiyetler arasında gözlenen bu farkın yapılan bağımsız örneklemler $t$-testi sonucuna göre anlamlı olduğu görülmektedir $(\mathrm{t}(324)=2.038, p<.05)$. Bu sonuca göre kadınların çalışma iradelerinin erkeklere göre anlamlı şekilde daha yüksek olduğu söylenebilir.

\section{Tartışma}

Bu çalışmanın ilk amacı üniversite öğrencilerinin sosyoekonomik durumları kontrol altına alındığında çalışma iradesinin kariyer karar verme öz-yetkinliği ve kariyer karar verme belirsizliğine tolerans tarafından ne düzeyde yordandığını incelemek; ikinci amacı ise çalışma iradesinin cinsiyete göre anlamlı bir fark gösterip göstermediğini belirlemektir.

Araştırmanın ilk amacı olan çalışma iradesinin sosyoekonomik durum kontrol altına alındığında KKVBT ve KKVÖY tarafından ne düzeyde yordandığını belirlemek için hiyerarşik regresyon analizi yapılmıştır. Analize ilk olarak sosyoekonomik durum girmiş, ardından ikinci blokta ise kariyer karar verme belirsizliğine tolerans değişkeninin üç alt boyutu ile kariyer karar verme öz-yetkinliği değişkeni sokulmuştur. Analiz sonucunda tüm değişkenler toplu olarak çalışma iradesini \%38 oranında anlamlı düzeyde yordamıştır. Sosyoekonomik durum 
kontrol altında tutulduğunda ise KKVBT ve KKVÖY birlikte çalışma iradesini \%29 oranında açıklamıştır. Değişkenlerin modele yaptıkları katkılar incelendiğinde sosyoekonomik durumun, kariyer karar verme belirsizliğine tolerans değişkeninin isteksizlik ve tercih alt boyutlarının ve kariyer karar verme öz-yetkinliğinin, çalışma iradesini tek başlarına anlamlı bir şekilde yordadıkları buna karşın tolerans alt boyutunun modele tek başına anlamlı bir katkı yapmadığı görülmüştür. Diğer yandan sosyoekonomik durum kontrol altına alındığında KKVÖY ve KKVBT’nin birlikte çalışma iradesini anlamlı bir şekilde yordayacağını ileri süren hipotez 1 doğrulanmıştır.

İlgili literatür incelendiğinde kariyer karar verme öz-yetkinliği ile çalışma iradesi arasındaki ilişkiye vurgu yapan çeşitli araştırmaların olduğu görülmektedir. Jadidian ve Duffy'nin (2012) yaptıkları bir araştırmada çalışma iradesi değişkeni kariyer karar verme öz-yetkinliğinin bir yordayıcısı olarak konumlandırılmış ve çalışma kontrol odağı değişkeninin aracı etkisiyle kariyer karar verme öz-yetkinliğinin ne düzeyde yordandığı incelenmiştir. Elde edilen bulgularda çalışma iradesinin kariyer karar verme öz-yetkinliğini anlamlı bir şekilde yordadığı görülmüştür. Duffy, Douglass ve Autin (2015) tarafından yapılan bir diğer çalışmada ise kariyer uyumluluğunun akademik doyum üzerindeki rolünde çalışma iradesi ve kariyer karar verme öz yetkinliği aracı değişkenler olarak belirlenmiş ve mevcut değişkenler arasındaki ilişkiye bakılmıştır. Elde edilen bulgulara göre çalışma iradesi ile kariyer karar verme öz-yetkinliği arasında pozitif yönde anlamlı bir ilişki olduğu görülmüştür. Bu çalışmaların mevcut çalışmanın bulgularıyla örtüştüğü söylenebilir. Mevcut çalışmadan elde edilen bulgular literatürle benzer olarak kariyer karar verme öz-yetkinliği ile çalışma iradesi değişkenleri arasında önemli bir ilişkinin olduğunu göstermektedir. Kariyer karar verme öz-yetkinliği yüksek bir bireyin kariyer karar verme sürecinde karşısına çıkabilecek güçlükleri aşmaya yönelik kendine duyduğu güven, o bireyin kendi sınırllıklarına rağmen bir karar verebilmesini ve süreç üzerindeki kontrol duygusunu artırabilir. Dolayısıyla öz-yetkinliğin çalışma iradesini pozitif yönde yordamasının beklenen bir sonuç olduğu söylenebilir. Buna göre kişilerin kariyer karar verme öz-yetkinliklerinde oluşabilecek bir değişimin çalışma iradelerine de yansıyabileceği düşünülebilir. Bu bağlamda özellikle çalışma iradesini desteklemeye yönelik geliştirilecek müdahale programlarında kariyer karar verme öz-yetkinliği de dahil edilerek danışanların daha fazla fayda görmeleri sağlanabilir.

Modele tek başına anlamlı katkı yapan diğer değişkenler ise Kariyer Karar Verme Belirsizliğine Tolerans Ölçeğinin tercih ve isteksizlik alt boyutlarıdır. Tercih alt boyutu kariyer karar verme sürecinde kişinin karşılaştığı belirsizlikleri çekici bulma eğilimini ifade ederken, isteksizlik alt boyutu ise bu belirsizliklerden kaçınmaya atıfta bulunmaktadır (Xu ve Tracey, 2015). Diğer bir deyişle iki alt boyutun belirsizliğe tolerans üzerinde iki farklı ucu yansıttığı söylenebilir. Kişinin sınırlılıklarının çeşitli belirsizlikleri ortaya çıkarabileceği düşünüldüğünde, kişinin belirsizliklere karşı tutumunun çalışma iradesinde değişikliğe yol açabileceği söylenebilir. İlgili literatürde bu konuda doğrudan yapılan bir çalışmaya rastlanmamıştır ancak Banning (2003) tarafından yapılan bir çalışmada belirsizliğe tolerans ile iç kontrol odağı arasında pozitif bir ilişki olduğu belirtilmiştir. Yine benzer bir çalışmada ise kadınların kendi hayatları üzerinde hissettikleri kontrol duygusu ile belirsizliğe tolerans düzeyleri arasında pozitif yönde bir ilişki bulunmuştur (Pawlicki ve Almquist, 1973). Çalışma iradesinin kişilerin kariyer karar verme süreçlerinde sahip oldukları sınırlılıklar üzerinde bir kontrol duygusu hissetmelerine ve bu sinırllıklara rağmen karar verebilme yeteneklerine atıfta bulunduğu düşünüldüğünde (Duffy, Douglass ve Autin, 2015) belirsizliğe tolerans gösterebilme düzeyinin çalışma iradesini yordayıcı bir etkiye sahip olduğu sonucuna varılabilir. Çünkü hem belirsizliğe tolerans kavramı hem de çalışma iradesi kavramı kişilerin mevcut güçlükler karşısında hissettiği kontrol duygusunu içinde barındırmaktadır. Bu yönüyle bakıldığında belirsizliğe toleransı yüksek olan bir kişinin mevcut sınırlılıklarına karşı karar verebilmeye yönelik algısının da yüksek olması beklenebilir.

Hiyerarşik regresyon analizi sonucunda sosyoekonomik durumun çalışma iradesini anlamlı bir şekilde tek başına yordadığı görülmektedir. Literatürde sosyoekonomik durum ile çalışma iradesi arasındaki ilişkiyi 
inceleyen oldukça az sayıda çalışma bulunmaktadır. Son yıllarda yapılan bir doktora çalışmasında (Wingate, 2020) araştırmacı, sosyoekonomik statünün çalışma iradesini doğrudan yordadığına yönelik bir bulgu ortaya koymuştur. Diğer taraftan Autin vd., (2017) da sosyoekonomik duruma benzer olarak sosyal statüyle çalışma iradesi arasında pozitif yönde bir ilişki olduğu sonucuna varmışlardır. Bu araştırma sonuçları mevcut araştırmanın bulgularıyla örtüşmektedir. Düşük sosyoekonomik durumun genel olarak eğitim alma ve kariyer seçimi konularında kişilerin önüne somut engeller çıkardığg söylenebilir. Dolayısıyla kişilerin ekonomik kaygılarının yüksek olması ve buna bağlı olarak nesnel olumsuzluklar ve engellerle karşılaşmaları onların sahip oldukları engeller karşısındaki algılarını olumsuz yönde etkileyecektir. Fakat kariyer psikolojik danışmanlığ 1 müdahalelerinin kişilerin sosyoekonomik durumlarında bir farklılık yaratması pek mümkün değildir. Bundan dolayı yapılan analizlerde sosyoekonomik durum değişkeninin çalışma iradesi üzerindeki etkisi kontrol altında tutulmuş ve KKVBT ile KKVÖY değişkenlerinin etkileri incelenmiştir. Yukarıda da belirtildiği gibi KKVBT ve KKVÖY değişkenleri sosyoekonomik durum kontrol altına alındığında çalışma iradesini anlamlı şekilde yordamaktadır. Bu sonuç ileride yapılacak kuramsal araştırmalara ve uygulama çalışmalarına önemli katkılar sağlayabilir. Bu katkılardan ilki çalışma iradesinin kuramsal olarak yapısının daha iyi anlaşılmasıdır. Kişilerin kariyer karar verme süreçleri içinde sahip oldukları çalışma iradelerinin yine bu süreç içinde karşılaşacakları belirsizliklere gösterdikleri toleransla ve öz-yetkinlik algısıyla ilişkili olduğu sonucu çalışma iradesinin içeriğinin daha net anlaşılmasına katkı sağlamaktadır. Araştırma sonuçlarının literatüre getirdiği diğer bir katkı ise çalışma iradesi kavramının Türk örneklemi üzerinde çalışılmasıdır. İlgili literatürde çalışma psikolojisi kuramının önemli değiş̧enlerinden biri olan çalışma iradesi kavramılla ilgili Türk örneklemi üzerinde oldukça az çalışmanın yapıldığı görülmektedir (Buyukgoze-Kavas, Duffy ve Douglass, 2015; Büyükgöze, 2018; Büyükgöze-Kavas ve Ünal, 2019). Dolayısıyla bu çalışmanın sonuçlarının Türkiye'de yapılacak olan çalışmaları artırabileceği düşünülmektedir.

Araştırmanın ikinci amacına yönelik olarak üniversite öğrencilerinin çalışma iradesinden aldıkları toplam puanların cinsiyete göre farklılaşıp farklılaşmadığı bağımsız örneklemler $t$-testi ile incelenmiştir. Yapılan analiz sonucunda kadın öğrencilerin Çalışma İradesi Ölçeği’nden aldıkları toplam puanların erkek öğrencilerin aldıkları toplam puanlara göre anlamlı bir şekilde yüksek olduğu bulunmuştur. Literatüre bakıldığında çalışma iradesi ile cinsiyet arasındaki ilişkiyi inceleyen oldukça az sayıda çalışmaya rastlanmaktadır. Örneğin, Duffy vd., (2012) tarafından yetişkin örneklemi üzerinde yapılan çalışma iradesi ölçeğinin geliştirilmesi çalışmasında kadınların çalışma iradelerinin erkeklere göre daha düşük olduğu sonucuna ulaşılmıştır. Bu sonucun mevcut araştırmanın bulgularıyla çeliştiği görülmektedir. Türkiye'de yetişkinlerle yapılan bir çalışmada (BüyükgözeKavas ve Ünal, 2019) ise çalışma iradesinde cinsiyetler arasında fark olmağı belirtilmiştir. Benzer şekilde üniversite öğrencileri üzerinde yapılan araştırmalarda ise çalışma iradesinin cinsiyet açısından farklılaşmadığını gösteren sonuçlar mevcuttur (Duffy, Diemer ve Jadidian, 2012; Duffy, Douglass, Autin ve Allan, 2016). Mevcut araştırmanın bulguları değerlendirildiğinde cinsiyet açısından kadınların lehine bir sonucun çlkmasının nedeni, çalışmanın üniversite öğrencileri üzerinde yürütülmüş olması olabilir. İlgili literatüre bakıldığında üniversite öğrencilerinde kadınların erkeklere göre daha eşitlikçi bir toplumsal cinsiyet algısına sahip oldukları belirtilmektedir (Aydın, Bekar, Gören ve Sungur, 2016; Belli ve Aynacı, 2020; KodanÇetinkaya, 2013). Bu bağlamda üniversite öğrencisi kadınlar karşılaştıkları engeller ve sınırlılıklarla eşitlikçi cinsiyet algıları sayesinde başediyor olabilirler ve bu sayede erkek öğrencilerden daha yüksek çalışma iradesine sahip olmuş olabilirler. Dolayısıyla üniversite öğrencileri için kadınların erkeklere göre daha yüksek çalışma iradesi algısına sahip olması beklenilen bir durum olarak değerlendirilebilir. Sonuç olarak çalışma iradesinin cinsiyete göre anlamlı bir farklılık gösterdiğini ileri süren hipotez 2 kabul edilmiştir. 


\section{Öneriler ve Sınırlılıklar}

Mevcut araştırmanın bulgularına dayalı olarak kariyer psikolojik danışmanlığı alanında çalışan araştırmacılara ve uygulayıcılara çeşitli öneriler getirilebilir. İlk olarak yukarıda da bahsedildiği gibi kariyer psikolojik danışmanlığı alanında önemli bir yere sahip olan çalışma iradesi kavramı farklı örneklemler üzerinde test edilebilir ve farklı değişkenlerle ilişkisi incelenerek kavramın yapısının daha net ortaya koyulması sağlanabilir. Diğer taraftan üniversite öğrencilerinin kariyer gelişimlerini açıklamak için çalışma iradesi boylamsal araştırma yöntemleriyle incelenebilir. Bunların haricinde öğrencilerin çalışma iradelerini güçlendirmeye yönelik geliştirilecek psikoeğitim programlarına da öğrencilerin belirsizliğe toleranslarını ve öz-yetkinlik düzeylerini artıracak müdahaleler eklenebilir.

Mevcut çalışma kendi içinde örneklemden kaynaklı bir sınırlılık barındırmaktadır. Bu sınırlılık örneklemin tek bir üniversiteden oluşturulmasıdır. Dolayısıyla elde edilen bulguların örneklem yapısı göz önünde bulundurularak değerlendirilmesi gerekmektedir. Bu sebeple gelecekte yapılacak çalışmalarda örneklemin evreni daha iyi yansıtacak şekilde farklı bölgelerden toplanması elde edilecek bulguların genellenebilirliğini artırabilir. Mevcut araştırmanın ilişkisel yönteme dayalı olarak yürütülmesi araştırmanın bir diğer sinırlılı̆g 1 olarak ifade edilebilir. Mevcut araştırmada değişkenler arasındaki ilişkiler ortaya konulmuştur ve bu değişkenler arasında bir neden sonuç ilişkisine dayalı bir çıkarımdan bahsetmek mümkün değildir. Dolayısıyla gelecek araştırmalarda deneysel desenlerle çalışma iradesinin incelenmesi kavramın diğer değişkenlerle olan neden-sonuç ilişkisini daha net ortaya koyabilir. Ayrıca çalışma iradesini artırmaya yönelik geliştirilecek psikoeğitim programlarına kariyer karar verme öz-yetkinliği ve belirsizliğe tolerans ile ilgili içeriklerin eklenmesi, söz konusu psikoeğitim programlarının etkililiğini daha da artırabilir. Diğer taraftan, toplumsal cinsiyet rolleri algısının da bundan sonraki çalışmalara dahil edilmesi, çalışma iradesi üzerindeki cinsiyet farklılıklarını açıklamada artı bir katkı sağlayabilir.

\section{Kaynakça}

Autin, K., Douglass, R., Duffy, R. D., England, J. ve Allan, B. (2017). Subjective social status, work volition, and career adaptability: A longitudinal study. Journal of Vocational Behavior, 99, 1-10. https://doi.org/10.1016/j.jvb.2016.11.007

Aydın, M., Bekar, E. Ö., Gören, Ş. Y. ve Sungur, M. A. (2016). Hemşirelik öğrencilerinin toplumsal cinsiyet

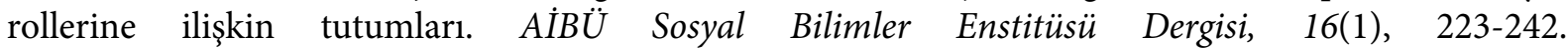
https://doi.org/10.11616/basbed.vi.455842

Banning, K. C. (2003). The effect of the case method on tolerance for ambiguity. Journal of Management Education, 27(5), 556-567. https://doi.org/10.1177/1052562903252652

Belli, A. ve Aynacı, G. (2020). Üniversite Öğrencilerinin Toplumsal Cinsiyet Rolleri Algısı: Kadınlar Kendilerini Nasıl Güçlendirebilir?. OPUS Uluslararası Toplum Araştırmaları Dergisi, 15(26), 4208-4229. https://doi.org/10.26466/opus.663605

Betz, N. E., Klein, K. L. ve Taylor, K. M. (1996). Evaluation of a short form of the career decision-making selfefficacy scale. Journal of Career Assessment, 4(1), 47-57. https://doi.org/10.1177/106907279600400103

Blustein, D. L. (2006). The psychology of working: A new perspection for career development, counseling and public policy. Mahwah, NJ: Lawrence Erlbaum. doi: 10.4324/978020203935477.

Blustein, D. L. (2008). The role of work in psychological health and well-being: a conceptual, historical, and public policy perspective. American Psychologist, 63(4), 228-240. https://doi.org/10.1037/0003066X.63.4.228 
Blustein, D. L., Kenna, A. C., Gill, N. ve DeVoy, J. E. (2008). The psychology of working: A new framework for counseling practice and public policy. The Career Development Quarterly, 56(4), 294-308. https://doi.org/10.1002/j.2161-0045.2008.tb00095.x

Boo, S. ve Kim, S. H. (2020). Career Indecision and Coping Strategies among Undergraduate Students. Journal of Hospitality \& Tourism Education, 32(2), 63-76. https://doi.org/10.1080/10963758.2020.1730860

Brown, S. D. ve Lent, R. W. (2005). Career development and counseling: Putting theory and research to work. Hoboken, NJ: John Wiley \& Sons.

Büyükgöze-Kavas, A. (2011). Testing a model of career indecision among university students based on social cognitive career theory. (Yayınlanmamış doktora tezi). Ortadoğu Teknik Üniversitesi/Sosyal Bilimler Enstitüsü, Ankara.

Buyukgoze-Kavas, A. (2014). A Psychometric Evaluation of the Career Decision Self-Efficacy Scale-Short Form With Turkish University Students. Journal of Career Assessment, 22(2), 386-397. https://doi.org/10.1177/1069072713484561

Büyükgöze, H. (2018). Üniversite öğrencilerinin proaktif kişiliklerinin çalışma iradesi algısındaki yordayıcı rolü. Kastamonu Eğitim Dergisi, 26(1), 117-123. https://dergipark.org.tr/en/pub/kefdergi/article/375678

Büyükgöze-Kavas, A. ve Ünal, Ş. (2019). Çalışma iradesi ölçeği: Geçerlik ve güvenirlik çalışması. Kariyer $\begin{array}{llll}\text { Psikolojik Danışmanlığı Dergisi, } & \text { 194-214. }\end{array}$ https://dergipark.org.tr/en/pub/kpdd/issue/51379/638160

Buyukgoze-Kavas, A., Duffy, R. D. ve Douglass, R. P. (2015). Exploring links between career adaptability, work volition, and well-being among Turkish students. Journal of Vocational Behavior, 90, 122-131. https://doi.org/10.1016/j.jvb.2015.08.006

Chen, Y. L. ve Fouad, N. A. (2013). Asian American educational goals: Racial barriers and cultural factors. Journal of Career Assessment, 21(1), 73-90. https://doi.org/10.1177/1069072712454700

Cheung, F., Ngo, H. ve Leung, A. (2018). Predicting work volition among undergraduate students in the United States and Hong Kong. Journal of Career Development, 4, 1-14. https://doi.org/10.1177/0894845318803469

Cohen, J. (1988). The t test for means. Statistical power analysis for the behavioural sciences. éd: Hillsdale, NJ: Lawrence Erlbaum http://www.utstat.toronto.edu/ brunner/oldclass/378f16/readings/CohenPower.pdf

Çokluk, Ö., Şekercioğlu, G. ve Büyüköztürk, Ş. (2012). Sosyal bilimler için çok değişkenli istatistik: SPSS ve LISREL uygulamaları (Vol. 2). Ankara: Pegem Akademi.

Duffy, R. D., Bott, E. M., Allan, B. A. ve Torrey, C. L. (2013). Examining a model of life satisfaction among unemployed adults. Journal of Counseling Psychology, 60, 53-63. https://doi.org/10.1037/a0030771

Duffy, R. D., Bott, E. M., Torrey, C. L. ve Webster, G. W. (2013). Work volition as a critical moderator in the prediction of job satisfaction. Journal of Career Assessment, 21, 20-31. https://doi.org/10.1177/1069072712453831

Duffy, R. D., Blustein, D. L., Diemer, M. A. ve Autin, K. L. (2016). The psychology of working theory. Journal of Counseling Psychology, 63(2), 127-148. https://doi.org/10.1037/cou0000140

Duffy, R. D., Diemer, M. A. ve Jadidian, A. (2012). The development and initial validation of the work volition scale-student version. The Counseling Psychologist, 40(2), 291-319. https://doi.org/10.1177/0011000011417147

Duffy, R. D., Diemer, M. A., Perry, J., Laurenzi, C., ve Torrey, C. (2012). The construction and initial validation of the work volition scale. Journal of Vocational Behavior, 80, 400-411. https://doi.org/10.1016/j.jvb.2011.04.002 
Duffy, R. D., Douglass, R. P. ve Autin, K. (2015). Career adaptability and academic satisfaction: Examining work volition and self efficacy as mediators. Journal of Vocational Behavior, 90, 46-54. https://doi.org/10.1016/j.jvb.2015.07.007

Duffy, R. D., Douglass, R. P., Autin, K. L. ve Allan, B. A. (2016). Examining predictors of work volition among undergraduate students. Journal of Career Assessment, 24, 441-459. https://doi.org/10.1177/1069072715599377

Fouad, N. A. (2007). Work and vocational psychology: Theory, research, and applications. Annual Review of $\begin{array}{llll}\text { Psychology, } & \text { 58, } & \text { 543ologylogyhologyyhoannurev.psych. } & \text { 58.110405.085713 }\end{array}$ https://doi.org/10.1146/annurev.psych.58.110405.085713

El-Hassan, K. ve Ghalayini, N. (2020). Parental attachment bonds, dysfunctional career thoughts and career exploration as predictors of career decision-making self-efficacy of Grade 11 students. British Journal of Guidance \& Guidance, 48(5), 597-610. https://doi.org/10.1080/03069885.2019.1645296

England, J. W., Duffy, R. D., Gensmer, N. P., Kim, H. J., Buyukgoze-Kavas, A. ve Larson-Konar, D. M. (2020). Women attaining decent work: The important role of workplace climate in Psychology of Working Theory. Journal of Counseling Psychology, 67(2), 251-264. https://doi.org/10.1037/cou0000411

Garcia, P., Restubog, S., Bordia, P., Bordia, S. ve Roxas, R. (2015). Career optimism: The roles of contextual support and career decision making self-efficacy. Journal of Vocational Behavior, 88, 10-18. https://doi.org/10.1016/j.jvb.2015.02.004

Gizir, C. A. (2005). Ortadoğu Teknik Üniversitesi son sınıf öğrencilerinin problemleri üzerine bir çalışma. Mersin Üniversitesi Eğitim Fakültesi Dergisi, 196-213. https://dergipark.org.tr/en/download/article-file/161013

Habibi, N. (2017). Higher education policies and overeducation in Turkey. European Journal of Higher Education, 7(4), 440-449. https://doi.org/10.1080/21568235.2017.1308832

Jadidian, A. ve Duffy, R. D. (2012). Work volition, career decision self efficacy, and academic satisfaction: An examination of mediators and moderators. Journal of Career Assessment, 20(2), 154-165. https://doi.org/10.1177/1069072711420851

Juntunen, C. ve Wettersten, K. B. (2006). Work hope: Development and initial validation of a measure. Journal of Counseling Psychology, 53(1), 94-106. https://doi.org/10.1037/0022-0167.53.1.94

Kelly, K. R. ve Pulver, C. A. (2003). Refining measurement of career indecision types: A validity study. Journal of Counseling and Development, 81, 445-454. https://doi.org/10.1002/j.1556-6678.2003.tb00271.x

Kim, N., Kim, H. ve Lee, K. (2018). Social support and occupational engagement among Korean Undergraduates: The moderating and mediating effect of work volition. Journal of Career Development, 45(3), 285-298. https://doi.org/10.1177/0894845316682319

Kirazc1, F. ve Öztemel, K. (2021). Üniversite öğrencilerinin kariyer karar verme belirsizliklerine toleranslarının çeşitli değişkenlerle ilişkilerinin incelenmesi. Mehmet Akif Ersoy Üniversitesi Eğitim Fakültesi Dergisi, 58, 442-477. https://dergipark.org.tr/en/pub/maeuefd/issue/61832/822514

Kodan-Çetinkaya, S. (2013). Üniversite öğrencilerinin şiddet eğilimlerinin ve toplumsal cinsiyet rollerine ilişkin tutumlarının incelenmesi. Nesne Dergisi, 1(2), 21-43. https://www.ceeol.com/search/articledetail id $=108002$

Lent, R., Brown, S. ve Hackett, G. (1994). Toward a unifying social cognitive theory of career and academic interest, choice, and performance. Journal of Vocational Behavior, 45, 79-122. https://doi.org/10.1006/jvbe.1994.1027

Masdonati, J., Schreiber, M., Marcionetti, J. ve Rossier, J. (2019). Decent work in Switzerland: Context, conceptualization, and assessment. Journal of Vocational Behavior, 110, 12-27. https://doi.org/10.1016/j.jvb.2018.11.004 
Miller, A. D. ve Rottinghaus, P. J. (2014). Career indecision, meaning in life, and anxiety: An existential framework. Journal of Career Assessment, 22(2), 233-247. https://doi.org/10.1177/1069072713493763

Özsoy, S. ve Özsoy, G. (2013). Eğitim araştırmalarında etki büyüklüğü raporlanması. İlköğretim Online, 12(2), 334-346. https://dergipark.org.tr/tr/pub/ilkonline/issue/8585/106644

Pallant, J. (2017). SPSS kullanma kılavuzu: SPSS ile adım adım veri analizi. (S. Balcı ve B. Ahi, Çev.) Ankara: Anı Yayınevi.

Patton, W. ve Creed, P. (2007). The relationship between career variables and occupational aspirations and expectations for Australian high school adolescents. Journal of Career Development, 34(2), 127-148. https://doi.org/10.1177/0894845307307471

Pavlicki, R. E. ve Almquist, C. (1973). Authoritarianism, locus of control, and tolerance of ambiguity as reflected in membership and nonmembership in a womens liberation group. Psychological Reports, 32, 1331-1337. https://doi.org/10.2466/pr0.1973.32.3c.1331

Sarı, S. V., Kabadayı, F. ve Şahin, M. (2017). Mesleki sonuç beklentisinin açıklanması: Öz-aşkınlık, öz-bilinç ve öz-kontrol/öz-yönetim. Türk Psikolojik Danışma ve Rehberlik Dergisi, 7(48), 145-159. http://acikerisim.erdogan.edu.tr/xmlui/handle/11436/5027

Storme, M., Celik, P. ve Myszkowski, N. (2019). Career decision ambiguity tolerance and career decisionmaking difficulties in a French sample: The mediating role of career decision self-efficacy. Journal of Career Assessment, 27(2), 273-288. https://doi.org/10.1177/1069072717748958

Tabachnick, B. G. ve Fidell, L. S. (2013). Çok değişkenli istatistiklerin kullanımı. (M. Baloğlu, Çev. Ed.). Ankara: Nobel Yayınevi.

Taylor, K. ve Betz, N. (1983). Applications of self-efficacy theory to the understanding and treatment of career indecision. Journal of Vocational Behavior, 22, 63-81. https://doi.org/10.1016/0001-8791(83)90006-4

Yerin Güneri, O. ve Çapa Aydın, Y. (2012). Most pressing counseling need of Turkish university students: Current and future career concerns. In IAEVG International Conference, Mannheim, Germany.

Yüksek Öğretim Kurumu. (2020). Yüksek öğretim bilgi yönetim sistemi: Öğrenim düzeyine göre öğrenci sayısı. https://istatistik.yok.gov.tr/

Wang, D., Jia, Y., Hou, Z. J., Xu, H., Zhang, H. ve Guo, X. L. (2019). A test of psychology of working theory among Chinese urban workers: Examining predictors and outcomes of decent work. Journal of Vocational Behavior, 115, 1-11. https://doi.org/10.1016/j.jvb.2019.103325

Wingate, J. A. (2020). Work hope and work volition: Exploring the influence of community college students' rurality and socioeconomic status. (Unpublished doctoral dissertation). Virgina Commonwealth University, Virgina. Erişim adresi: https://scholarscompass.vcu.edu/etd/6132

$\mathrm{Xu}, \mathrm{H}$. (2020). The ripple prediction of ambiguity aversion in career decision-making. Journal of Counseling Psychology, 67(1), 123-149. https://doi.org/10.1037/cou0000354

Xu, H., Hou, Z. J., Tracey, T. J. ve Zhang, X. (2016). Variations of career decision ambiguity tolerance between China and the United States and between high school and college. Journal of Vocational Behavior, 93, 120-128. https://doi.org/10.1016/j.jvb.2016.01.007

Xu, H. ve Tracey, T. J. (2014a). The role of ambiguity tolerance in career decision making. Journal of Vocational Behavior, 85(1), 18-26. https://doi.org/10.1016/j.jvb.2014.04.001

$\mathrm{Xu}, \mathrm{H}$. ve Tracey, T. J. (2014b). Ambiguity tolerance with career indecision; An examination of the mediation effect of career decision making self-efficacy. Journal of Career Assessment, 23(4), 519-532. https://doi.org/10.1177/1069072714553073

$\mathrm{Xu}, \mathrm{H}$. ve Tracey, T. J. (2015). Career decision ambiguity tolerance scale: Construction and initial validations. Journal of Vocational Behavior, 88, 1-9. https://doi.org/10.1016/j.jvb.2015.01.006 


\section{Extended Abstract}

\section{Purpose}

The increase in the number of students studying at the undergraduate level brings some problems related to university graduates' employment (Habibi, 2017). Studies on the career development of undergraduates indicate that one of the main problems faced by university students is difficulty in making decisions about their career and not knowing what to do after graduation (Boo \& Kim, 2020; Gizir, 2005; Kelly \& Pulver, 2003; Miller \& Rottinghaus, 2014; Yerin-Guneri \& Capa-Aydin, 2012). In this context, it is crucial to reveal the factors that make it easier for students to decide about their careers consciously and construct their careers. Post-modern career approaches underline the critical role of many contextual issues such as economic constraints and marginalization on a career decision. Therefore, the aim of the present study is to investigate the predicting role of career decision self-efficacy and career decision ambiguity tolerance on work volition while socioeconomic status is controlled.

\section{Design and Methodology}

Participants of the study consisted of 327 (226 women, 100 men, one gender unspecified) undergraduate students. The ages of the participants ranged from 19 to $38(\bar{x}=21.61$; Ss $=1.89)$. We used convenience sampling method to collect data. The faculties where the participants were recruited; Education (95\%, 29.1\%), Fine Arts (85\%, 26\%), Engineering (60\%, 18.3\%), Dentistry (42\%, 12.8\%), Science and Literature (37, 11.3\%). We collected the data by using three scales and a demographic information form.

The Work Volition Scale - Student Form was developed by Duffy, Diemer, and Jadidian (2012) to measure individuals' perceptions of professional decision-making despite their limitations. The scale consisted of 16 items and two subscales, namely constraints and volition. The Turkish version of the scale was validated by Buyukgoze-Kavas, Duffy, and Douglas (2015). The internal consistency coefficient study was calculated as .93. Career Decision Self-Efficacy Scale-Short Form was developed to measure "an individual's degree of belief that he or she can successfully complete tasks necessary to making career decisions" (Betz et al., 1996, p. 48). For the short form of the scale, Betz et al. (2005) reported the internal consistency as .94 for the total score. The Turkish form of the scale was validated by Buyukgoze-Kavas $(2011,2014)$ and the Cronbach alpha coefficient was found .92 for the total score.

Career Decision Ambiguity Tolerance Scale was developed by Xu and Tracey (2015) to measure individuals' level of tolerance to uncertain situations they encounter in career decision-making processes. The scale, consisting of 18 items in total, has a three-factor structure (preference, tolerance, and aversion). In addition, the internal consistency coefficients of the sub-dimensions were found as .83 for preference, .70 for tolerance, and .81 for aversion, respectively. Validation study of the Career Decision Ambiguity Tolerance Scale to Turkish was carried out by Kirazcı and Öztemel (2019).

\section{Findings}

We prior to testing our hypoheses, we conducted several analysis to find out whether the data set conforms to the assumptions of our analyzes. First, we examined whether the data set is normally distributed. Then we assessed whether there is multiple colinearity between variables. To test this assumption, we examined the correlation coefficients between variables and variance inflation factors of independent variables. As a result of the analysis, it was concluded that all the assumptions were provided. Then we performed independent sample $t$-test analysis and hierarchical regression analysis to test our hypotheses. According to the results of the independent samples $t$-test, work volition of women was found to be significantly higher than work volition of men $(t(324)=2.038, p<.05)$. Then we performed a hierarchical regression analysis to examine to what extent career decision self-efficacy and career decision ambiguity tolerance together predicted work volition 
when the socioeconomic status was under control. According to the hierarchical regression analysis, it was concluded that all independent variables predicted $38 \%$ of work volition $\left(\mathrm{R}^{2}=.38, \mathrm{~F}(5-326)=39.273, p<.001\right)$. When the socioeconomic status was kept under control, preference, tolerance, and aversion and career decision self-efficacy together explain $29 \%$ of work volition. In order to examine the effect size of the hierarchical regression analysis results, $\mathrm{f}^{2}$ effect size value was calculated. As a result of the calculation, it was concluded that the effect size of the present study has a wide effect $\left(\mathrm{f}^{2}=.613\right)$.

\section{Limitations}

Current study has a couple of limitations. Firstly the sample was collected only one university. For this reason the findings should be evaluated considering this situation. Therefore, in future studies, data can be collected from different regions in a way to better reflect the sample. Another limitations of the current research is that it is based on the relational method. Therefore, only the relationships between variables have been revealed in the present study. So, a cause-effect relationship can not be mentioned in the present study. In future studies, a cause-effect relationship can be revealed by reworking existing variables with experimental designs.

\section{Implications}

Based on the findings of the current study, we can make several recommendations for future research. Work volition can be tested on different samples in order to better understand the variable. Similarly, studying work volition with different variables can contribute to better understanding of the structure of the variable. On the other hand, in order to explain the career development of university students, work volition can be examined by longitudinal research methods. Apart from these implications, various psychoeducational programs can be developed to strengthen students' work volition. Interventions to develop career decision self-efficacy and tolerance of ambiguity can be added to these developed programs.

\section{Originality}

Work volition, one of the significant variables of psychology of working theory, has an important place in individuals' career decisions. Although there are many studies about work volition in the literature, there are very few studies on the Turkish sample. The examination of work volition to study on Turkish sample constitutes a unique aspect of the present study. Another original aspect of the study is that work volition is examined with career decision ambiguity tolerance. We believe that the theoretical structure of the work volition will be revealed more clearly with present study.

Araştırmacı Katkısı: Furkan KİRAZCI (\%70), Ayşenur BÜYÜKGÖZE KAVAS (\%30). 